\title{
Characteristics of regional new particle formation in urban and regional background environments in the North China Plain
}

\author{
Z. B. Wang ${ }^{1,3,{ }^{*}}$, M. Hu ${ }^{1}$, J. Y. Sun ${ }^{2}$, Z. J. Wu ${ }^{1,3}$, D. L. Yue ${ }^{1}$, X. J. Shen ${ }^{2}$, Y. M. Zhang ${ }^{2}$, X. Y. Pei ${ }^{1,4}$, Y. F. Cheng ${ }^{5}$, and \\ A. Wiedensohler ${ }^{3}$ \\ ${ }^{1}$ State Key Joint Laboratory of Environmental Simulation and Pollution Control, College of Environmental Sciences and \\ Engineering, Peking University, Beijing 100871, China \\ ${ }^{2}$ Key Laboratory for Atmospheric Chemistry, Chinese Academy of Meteorological Sciences, Beijing 100081, China \\ ${ }^{3}$ Leibniz Institute for Tropospheric Research, Permoserstr. 15, Leipzig 04318, Germany \\ ${ }^{4}$ Department of Chemistry and Molecular Biology, Atmospheric Science, University of Gothenburg, Gothenburg 41296, \\ Sweden \\ ${ }^{5}$ Multiphase Chemistry Department, Max Planck Institute for Chemistry, Mainz 55128, Germany \\ * now at: Multiphase Chemistry Department, Max Planck Institute for Chemistry, Mainz 55128, Germany
}

Correspondence to: M. Hu (minhu@pku.edu.cn) and J. Y. Sun (jysun@cams.cma.gov.cn)

Received: 16 July 2013 - Published in Atmos. Chem. Phys. Discuss.: 7 August 2013

Revised: 27 November 2013 - Accepted: 27 November 2013 - Published: 20 December 2013

\begin{abstract}
Long-term measurements of particle number size distributions were carried out both at an urban background site (Peking University, PKU) and a regional Global Atmospheric Watch station (Shangdianzi, SDZ) from March to November in 2008. In total, 52 new particle formation (NPF) events were observed simultaneously at both sites, indicating that this is a regional phenomenon in the North China Plain. On average, the mean condensation sink value before the nucleation events started was $0.025 \mathrm{~s}^{-1}$ in the urban environment, which was 1.6 times higher than that at regional site. However, higher particle formation and growth rates were observed at PKU $\left(10.8 \mathrm{~cm}^{-3} \mathrm{~s}^{-1}\right.$ and $\left.5.2 \mathrm{~nm} \mathrm{~h}^{-1}\right)$ compared with those at SDZ $\left(4.9 \mathrm{~cm}^{-3} \mathrm{~s}^{-1}\right.$ and $\left.4.0 \mathrm{~nm} \mathrm{~h}^{-1}\right)$. These results implied that precursors were much more abundant in the polluted urban environment. Different from the observations in cleaner environments, the background conditions of the observed particle homogeneous nucleation events in the North China Plain could be characterized as the co-existing of a stronger source of precursor gases and a higher condensational sink of pre-existing aerosol particles. Secondary aerosol formation following nucleation events results in an increase of particle mass concentration, particle light scattering coefficient, and cloud condensation nuclei $(\mathrm{CCN})$ number concentration, with consequences on visibility, radiative effects, and air quality. Typical regional NPF events with
\end{abstract}

significant particle nucleation rates and subsequent particle growth over a sufficiently long time period at both sites were chosen to investigate the influence of NPF on the number concentration of "potential" CCN. As a result, the NPF and the subsequent condensable growth increased the $\mathrm{CCN}$ number concentration in the North China Plain by factors in the range from 5.6 to 8.7. Moreover, the potential contribution of anthropogenic emissions to the $\mathrm{CCN}$ number concentration was more than $50 \%$, to which more attention should be drawn in regional and global climate modeling, especially in the polluted urban areas.

\section{Introduction}

Impacts of aerosol particles on the earth-atmosphere system, including the climate, ecosystem, air quality and public health, determine its highlighted topics in atmospheric environmental research (IPCC, 2007). New particle formation (NPF), through the nucleation of gas-phase species and continuous condensational growth, is an important source of aerosol particles on a global scale (Merikanto et al., 2009; Yu et al., 2008). These newly formed particles can grow into sizes in which they can act as potential cloud condensation nuclei $(\mathrm{CCN})$ and in this way influence the regional 
and global climate system indirectly (Kerminen et al., 2012; Lohmann and Feichter, 2005). On the other hand, in environments such as the North China Plain (NCP) with a high potential of secondary aerosol formation and a strong subsequent condensational growth (Wiedensohler et al., 2009), the particle light scattering coefficient can also be significantly increased as shown in Shen et al. (2011).

NPF events have been observed in a variety of atmospheric environments including the stratosphere (Lee et al., 2003), remote polar area (Park et al., 2004), high-altitude mountains (Venzac et al., 2008; Weber et al., 1997), inside boreal forests (Dal Maso et al., 2005), coastal environments (O'Dowd et al., 2002), continental rural and suburban regions (Birmili et al., 2003; Petäjä et al., 2007), as well as urban environments (McMurry et al., 2005; Salma et al., 2011; Stanier et al., 2004) and very polluted megacities such as Mexico City (Dunn et al., 2004), New Delhi (Mönkkönen et al., 2005) and Beijing (Wu et al., 2007). Meanwhile, evidence also has revealed that ambient new particle formation might take place on a larger regional scale (Bae et al., 2010; Dal Maso et al., 2007; Hussein et al., 2009; Jung et al., 2013; Tunved et al., 2003). Kulmala et al. (2004) summarized the formation and growth properties based on over 100 field campaigns. The results showed that the typical particle growth rates in nucleation mode range from 1 to $20 \mathrm{~nm} \mathrm{~h}^{-1}$ in mid-latitudes, whereas particle formation rates vary widely depending on the air mass type of sampling site. However, most of these measurements were conducted in Europe and North America or they were limited for a short time period; long-term observations, especially carried out in developing countries, were quite rare.

In China, long-term continuous measurements of particle number size distributions have been performed in urban Beijing (Peking University, PKU) since March 2004 (Wehner et al., 2004) and at the regional background station Shangdianzi (SDZ) since March 2008 (Shen et al., 2011). High frequencies of NPF events were observed around the Beijing region. In addition, the NPF events also had been observed in a marine area (Lin et al., 2007), high-elevation mountains (Guo et al., 2012; Kivekas et al., 2009; Li et al., 2011), rural sites of Pearl River delta (Liu et al., 2008; Wang et al., 2013c), suburban environments in Yangtze River delta region (Gao et al., 2009; Herrmann et al., 2013) and Lanzhou (Gao et al., 2011), as well as urban Shanghai (Du et al., 2012). These observations were however independent and only based on short-term observations. No information on the long-term measurements of NPF events on a regional scale has been reported yet.

Regional NPF events had been observed in the Beijing area based on the simultaneous long-term measurements of particle number size distributions both at PKU and SDZ sites from March to November 2008. In this study, we are aiming to investigate the relationship of NPF events between polluted urban and regional background environments. This is the first kind of study in China based on a long-term data set. The characteristics are compared, and the influences of NPF events on the direct (particle light scattering coefficient) and indirect (CCN number concentration) aerosol effects are evaluated.

\section{Measurements}

\subsection{Sampling site}

The urban sampling site PKU is located in the northwest of the center of Beijing, outside the 4th Ring Road. The observatory is set on the sixth floor of an academic building on the campus of Peking University $\left(39.99^{\circ} \mathrm{N}, 116.31^{\circ} \mathrm{E}\right.$; $50 \mathrm{~m}$ a.s.1.). Two major roads with heavy traffic to the east and south of the site are respectively $200 \mathrm{~m}$ and $500 \mathrm{~m}$ away. The PKU site is assumed as representative of a typical urban site of Beijing. For detailed descriptions of the measurement site, we refer the reader to Wu et al. (2008).

The SDZ site $\left(40.65^{\circ} \mathrm{N}, 117.28^{\circ} \mathrm{E} ; 287 \mathrm{~m}\right.$ a.s.l. $)$ is one of the regional stations of the Global Atmosphere Watch (GAW) program in China. This station is located in the northern part of the North China Plain, about $120 \mathrm{~km}$ northeast of the PKU site. The sampling site is situated on the south slope of the Yanshan Mountains, in the valley with a northeastsouthwest orientation. There are few local anthropogenic pollution sources surrounding the SDZ site, which could reflect the regional background situation for the North China Plain. Detailed information on the SDZ site can be found in Shen et al. (2011).

\subsection{Instrumentation}

Number size distributions of atmospheric particles in the size range 3-900 nm at the PKU site and 3-850 $\mathrm{nm}$ at the SDZ site were both measured by a dual mobility particle size spectrometer (TROPOS-type TDMPS: twin differential mobility particle sizer) (Birmili et al., 1999). The whole system consists of two parallel Hauke-type differential mobility analyzers (DMAs) and two condensation particle counters (CPCs) (model 3010 and model 3025, TSI Inc., St. Paul, MN, USA). The relative humidity $(\mathrm{RH})$ within the whole system was kept below $40 \%$ both in the inlet line and in the sheath air cycle to obtain the number size distributions of dry particles. In addition, the particle number size distributions were corrected for particle losses inside the mobility particle size spectrometers and in the sampling configuration, following the method of the "equivalent length" as described in Wiedensohler et al. (2012).

\subsection{Data analysis}

\subsubsection{Classification scheme}

The event classification criterion is based on the method described by Dal Maso et al. (2005). However, the nucleation 
events are only divided into two groups in this study. The criterion for discerning an intensive nucleation event day (Class I) is the burst of new particles in the nucleation mode size range of 3-25 nm, and the burst should last several hours with a clear growth pattern. On some days, the formation of new particles was observed without subsequent growth. These cases are more likely the sudden burst of freshly nucleated particles, which are grouped into Class II. Besides these two kinds of NPF events, the sporadic occurrence of newly formed particles in the nucleation mode size range was also seen. However, the situation does not fulfill the criteria for the event days. These days are represented as "undefined".

\subsubsection{Particle formation rate (FR) and growth rate (GR)}

The lowest detecting particle size measured by the mobility particle size spectrometer is $3 \mathrm{~nm}$. Hence, apparent formation rate $\left(J_{3}\right)$ can be expressed as

$J_{3}=\mathrm{d} N_{\text {nuc }} / \mathrm{d} t+F_{\text {coag }}+F_{\text {growth }}$.

Here, $N_{\text {nuc }}$ is the number concentration of nucleation mode particles. $F_{\text {coag }}$ and $F_{\text {growth }}$ represent the loss of particles due to coagulation and the flux of particles out of the specified size range, respectively. The second term in Eq. (1) can be calculated according to

$F_{\text {coag }}=\mathrm{CoagS}_{\text {nuc }} N_{\text {nuc }}$,

in which $\mathrm{CoagS}_{\text {nuc }}$ is the coagulation sink of nucleation mode particles. In this study, we consider the reference size for the coagulation sink to be the geometric mean diameter of nucleation mode $(8 \mathrm{~nm})$. CoagS $\mathrm{S}_{\text {nuc }}$ is defined as

$\operatorname{CoagS}\left(D_{\mathrm{p}}\right)=\int K\left(D_{\mathrm{p}}^{\prime}, D_{\mathrm{p}}\right) n\left(D_{\mathrm{p}}^{\prime}\right) \mathrm{d} D_{\mathrm{p}}^{\prime}$.

Here, $K\left(D_{\mathrm{p}}^{\prime}, D_{\mathrm{p}}\right)$ is the coagulation coefficient of particles with diameters $D_{\mathrm{p}}$ and $D_{\mathrm{p}}^{\prime}$ according to Fuchs (1964). The newly formed particles rarely grow beyond $25 \mathrm{~nm}$ before the end of formation, and the last term can be neglected (Dal Maso et al., 2005).

The observed particle growth rate is calculated based on the "lognormal distribution function method" described by Kulmala et al. (2012). Typical particle number size distributions are fitted by a least-square lognormal fitting method yielding parameters of 2-3 lognormal modes. Thus, the temporal variation of mean geometric diameters could be obtained, and the particle growth rate can be estimated (GR = $\mathrm{d} D_{\mathrm{p}} / \mathrm{d} t$, given in $\mathrm{nm} \mathrm{h}^{-1}$ ).

Moreover, we should keep in mind that the determinations of start and end times of nucleation events in Class II type are difficult, which might cause huge uncertainty when calculating the particle formation and growth rates. Therefore, in this study we only focus on the nucleation events in Class I type, which show both the clear nucleation and growth diurnal patterns.

\subsubsection{Condensation sink (CS), condensable vapor concentration $(C)$ and source rate $(Q)$}

The condensation sink, which describes how rapidly vapor molecules can condense onto the particles, is used to represent the pre-existing particles concentration (Kulmala et al., 2001). The CS values can be directly obtained from the measured particle number size distributions, and expressed as

$\mathrm{CS}=2 \pi D \sum \beta D_{\mathrm{p}} N$.

Here, $D$ is the diffusion coefficient of the condensing vapor, $\beta$ the transitional regime correction factor, $D_{\mathrm{p}}$ the particle diameter and $N$ the corresponding particle number concentration. However, note that the CS values are achieved based on the dry particle number size distributions in this study, which could not necessarily represent ambient wet conditions well, especially during the humid summertime. Hence, the presented CS values might be underestimated compared with the real ones. The uncertainty caused by the typical effect of hygroscopic growth on CS is between $5 \%$ and $50 \%$ as shown in previous research (Kulmala et al., 2001).

The condensable vapor concentration $C$ and its source rate $Q$ could be achieved based on the growth rate and the condensation sink (Kulmala et al., 2001). The growth rate depends on the amounts of condensable vapors in the atmosphere. Hence, the vapor concentration could be obtained by

$C=C_{\mathrm{GR}=1 \mathrm{nmh}^{-1}} \times \mathrm{GR}$.

Here, $C_{\mathrm{GR}=1 \mathrm{nmh}^{-1}}$ is the vapor concentration required for growth rate of $1 \mathrm{~nm} \mathrm{~h}^{-1}$. A recent study (Nieminen et al., 2010) gave Eq. (6) to get its value:

$$
\begin{aligned}
& C_{\mathrm{GR}=1 \mathrm{nmh}^{-1}}=\frac{2 \rho_{v} d_{v}}{\gamma m_{v} \Delta t} \cdot \sqrt{\frac{\pi m_{v}}{8 k T}} \\
& \cdot\left[\frac{2 x_{1}+1}{x_{1}\left(x_{1}+1\right)}-\frac{2 x_{0}+1}{x_{0}\left(x_{0}+1\right)}+2 \ln \left(\frac{x_{1}\left(x_{0}+1\right)}{x_{0}\left(x_{1}+1\right)}\right)\right] .
\end{aligned}
$$

Here we assume the properties of the condensable vapors are similar to gaseous sulfuric acid, which has been proven to be the key component in the nucleation process (Berndt et al., 2005; Chen et al., 2012; Sipila et al., 2010; Zhang et al., 2012). The mass $\left(m_{v}\right)$ and density $\left(\rho_{v}\right)$ of hydrated sulfuric acid vapor molecule utilized in this study are $135 \mathrm{amu}$ and $1650 \mathrm{~kg} \mathrm{~m}^{-3}$, respectively (Wang et al., 2013b).

With a pseudo-steady-state assumption, the vapor source rate can be estimated as

$Q=\mathrm{CS} \cdot C$,

where $Q$ is the condensable vapor source rate in units of $\mathrm{cm}^{-3} \mathrm{~s}^{-1}$. 
Table 1. Classification statistics of events at PKU and SDZ. $N(\%): N$ is the number of each class, and the value in parentheses indicates the percentage accounting for the days with valid data.

\begin{tabular}{lrrrrrr}
\hline Site & Class I & Class II & Non-event & Undefined & Valid & Bad/missing \\
\hline PKU & $67(26 \%)$ & $29(12 \%)$ & $80(32 \%)$ & $77(30 \%)$ & 253 & 22 \\
SDZ & $69(31 \%)$ & $18(8 \%)$ & $87(39 \%)$ & $49(22 \%)$ & 223 & 52 \\
\hline
\end{tabular}

\section{Results and discussions}

\subsection{Occurrence of new particle formation event}

The investigation time period is from March to November 2008, during which the simultaneous measurements of particle number size distributions were performed at both sites. The numbers of days with valid data were 253 at PKU and 223 at SDZ, respectively, accounting for $92 \%$ and $81 \%$ of the total 275 investigated days (Table 1). For the other days, data were either completely missing or had a poor quality. The frequencies of NPF events were $38 \%$ and $39 \%$ in classified days at urban and regional sites, respectively. These frequencies are consistent with those observed in Beijing between March 2004 and February 2005 (Wu et al., 2007). One third of nucleation events at PKU were the Class II type, which was higher than that at SDZ (21\%). This might be due to the influences of local emissions such as traffic near the urban site. For several days with the NPF event shown at PKU, we only observed a similar particle growth pattern at SDZ. However, aerosol particles in the size range of 3$10 \mathrm{~nm}$ were not observed. This feature seems like influenced by the regional transportation between these two sites. In total, 52 NPF events were observed simultaneously at both places based on 207 valid days with simultaneous measurements, suggesting the new particle formation is a regional phenomenon over the North China Plain.

Similar "U-shaped" seasonal variation patterns of NPF event occurrence were observed at both sites, as shown in Fig. 1. The number of events was highest in the spring months (March-May), with 43 cases, occurring at both PKU and SDZ, respectively, accounting for $45 \%$ and $49 \%$ of the total number of observed NPF events. That more events were observed in spring may due to a higher frequency of strong wind from northern China, which favors removing the preexisting particles in the atmosphere and further leads to the occurrence of NPF events (Wu et al., 2008). During summertime, high temperatures and RHs are not favorable for NPF events. Slowly moving air masses from regions south of Beijing, which dominates during summertime, contain significantly more accumulation mode particles, resulting in pollution episodes (Wang et al., 2013a; Wehner et al., 2008). Hence, only few events (22 at PKU and 10 at SDZ) were observed during this time period. More NPF events were observed in autumn at SDZ (43 cases) compared with at PKU (31 cases), especially in October and November. This might

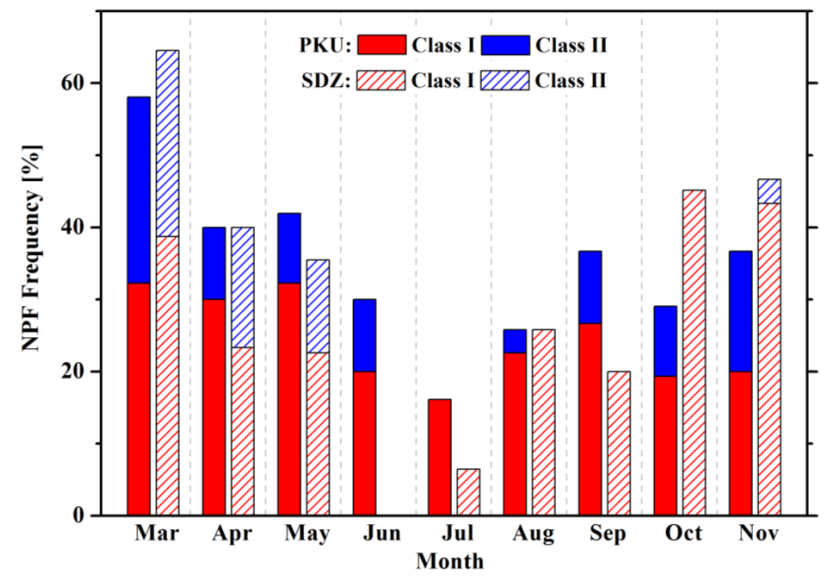

Fig. 1. The frequencies of NPF events versus month at two sites during the whole measurement period.

be owed to the heavy pollution episodes with poor dispersion of pollutants that always take place in urban Beijing in this season (Wu et al., 2008). On the contrary, there are fewer pre-existing particles at the SDZ site, which favors producing more events.

\subsection{Nucleation event characterization}

Individual and mean formation rates of aerosol particles greater than $3 \mathrm{~nm}$ are shown in Fig. 2a. They varied in the range from $2.2 \mathrm{~cm}^{-3} \mathrm{~s}^{-1}$ to $34.5 \mathrm{~cm}^{-3} \mathrm{~s}^{-1}$ at PKU, and from 0.4 to $24.5 \mathrm{~cm}^{-3} \mathrm{~s}^{-1}$ at SDZ. In addition, the mean value was $10.8 \mathrm{~cm}^{-3} \mathrm{~s}^{-1}$ at PKU, which was a factor of two higher than that at $\operatorname{SDZ}\left(4.9 \mathrm{~cm}^{-3} \mathrm{~s}^{-1}\right)$. The formation rates at both sites were significantly higher than the observations in clean environments such as $0.8 \mathrm{~cm}^{-3} \mathrm{~s}^{-1}$ in Hyytiälä (Dal Maso et al., 2005) and $1 \mathrm{~cm}^{-3} \mathrm{~s}^{-1}$ in Hohenpeissenberg (Birmili et al., 2003). However, the values at PKU are also much higher than observed at other urban sites such as Helsinki $\left(2.4 \mathrm{~cm}^{-3} \mathrm{~s}^{-1}\right.$; Hussein et al., 2008) and Budapest $\left(4.2 \mathrm{~cm}^{-3} \mathrm{~s}^{-1}\right.$; Salma et al., 2011), as well as in similar magnitude with study in New Delhi (3.3-13.9 $\mathrm{cm}^{-3} \mathrm{~s}^{-1}$; Mönkkönen et al., 2005) and St. Louis (17 $\pm 20 \mathrm{~cm}^{-3} \mathrm{~s}^{-1}$; Qian et al., 2007). The highest formation rates were shown at both sites in spring (Fig. 2b), which can be explained by the favorable meteorological conditions such as low temperature and humidity as well as strong north wind, bringing the clean air mass in this season, as detailed in Wu et al. $(2008,2007)$ and Shen et al. (2011). 

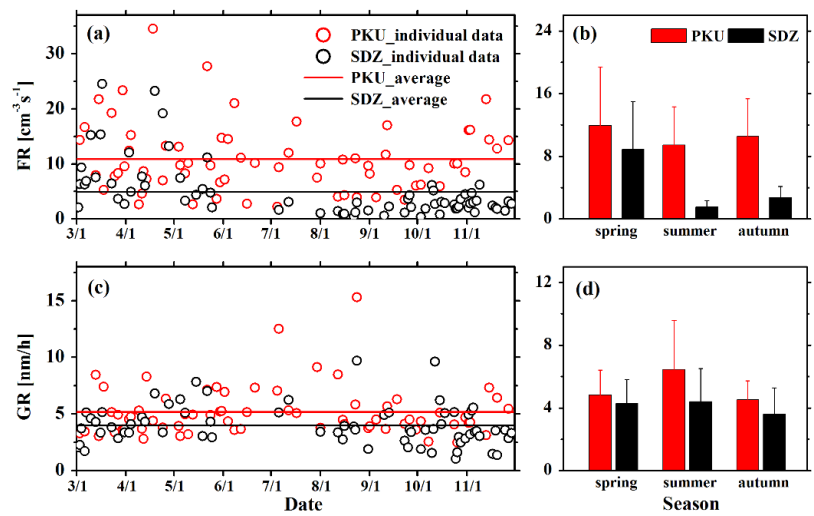

Fig. 2. The variations of particle formation rates (FR, a, b) and growth rate $(\mathrm{GR}, \mathbf{c}, \mathbf{d})$ at PKU (red) and SDZ (black) during the measurement period. The bars in (b) and (d) indicate the standard deviation.

Growth rates ranged from $2.5 \mathrm{~nm} \mathrm{~h}^{-1}$ to $15.3 \mathrm{~nm} \mathrm{~h}^{-1}$ with a mean and standard deviation of $5.2 \pm 2.2 \mathrm{~nm} \mathrm{~h}^{-1}$ at the PKU site, which was slightly higher than the values at SDZ (1.0 $9.7 \mathrm{~nm} \mathrm{~h}^{-1}, 4.0 \pm 1.7 \mathrm{~nm} \mathrm{~h}^{-1}$ ). They essentially fit into the range of typical particle growth rate of $1-20 \mathrm{~nm} \mathrm{~h}^{-1}$ (Kulmala et al., 2004). Contrary to the particle formation rate, the highest growth rate is observed in summertime, when the enhancement of photochemical and biological activities contributed to the particle growth. This is consistent with a previous study (Wu et al., 2007).

More CS of pre-existing aerosol particles was found as expected in the urban environment (see Fig. 3). The mean CS values on NPF event days were $0.027 \pm 0.021 \mathrm{~s}^{-1}$ and $0.020 \pm 0.020 \mathrm{~s}^{-1}$ at PKU and SDZ, respectively. These values were significantly lower than those during nonevent days $\left(0.047 \pm 0.024 \mathrm{~s}^{-1}\right.$ and $\left.0.026 \pm 0.018 \mathrm{~s}^{-1}\right)$. During NPF event days, the CS values were 5-10 times higher than those observed in European cities such as Marseille $\left(0.003-0.015 \mathrm{~s}^{-1}\right)$, Athens $\left(0.006-0.013 \mathrm{~s}^{-1}\right)$ or Helsinki $\left(0.006 \mathrm{~s}^{-1}\right)$. The highest value was however comparable with the polluted city New Delhi $\left(0.050-0.070 \mathrm{~s}^{-1}\right)$ (Hussein et al., 2008; Kulmala et al., 2005). It is remarkable that the mean CS value of $0.025 \mathrm{~s}^{-1}$ before the nucleation events started (08:00-11:00) at the PKU site was close to the CS of $0.024 \mathrm{~s}^{-1}$ at SDZ during non-event days. This result implied that more precursors are needed for the new particle formation event to be observed in a polluted urban environment.

Table 2 lists the statistical results of the condensation sink, condensable vapor concentration and its source rate. The seasonal variations of vapor concentration and its source rate showed that the highest values during summer months. This result is consistent with the previous study by $\mathrm{Wu}$ et al. (2007). The vapor concentration at PKU $\left(9.3 \times 10^{7} \mathrm{~cm}^{-3}\right)$ was 1.3 times higher than that at SDZ $\left(7.1 \times 10^{7} \mathrm{~cm}^{-3}\right)$ during the whole measurement period. It is easy to understand that more vapors should be involved in the particle growth

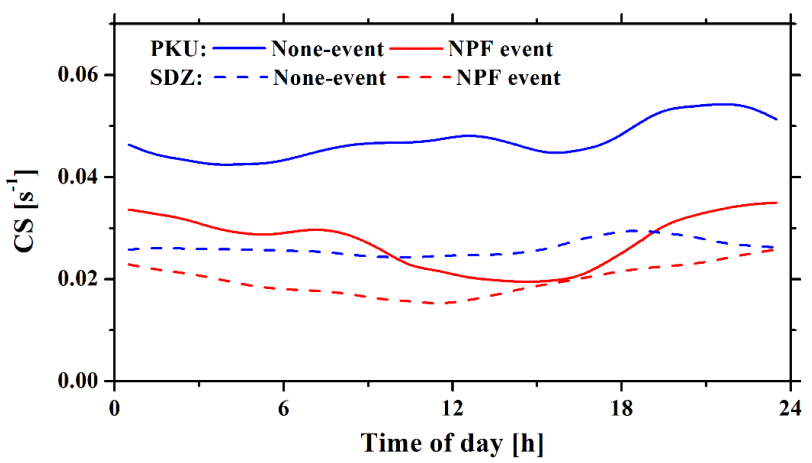

Fig. 3. Diurnal variations of condensation sink (CS) in the NPF event (red) and non-event (blue) at PKU (solid line) and SDZ (dash line).

processes to prevent the newly formed particles from being captured by more pre-existing accumulation mode particles in a polluted urban environment. As a result, the source rate of condensable vapor was on average 1.8 times higher at urban PKU compared to the SDZ. Overall, unlike the observations in cleaner environments, the background conditions of NPF events in the North China Plain could be characterized as the greater source strength for condensable vapors and higher CS of pre-existing particles, even in the regional background.

\subsection{Influences on the light scattering and $\mathrm{CCN}$ production}

Particle light scattering could be distinctly increased as a result of condensational growth following a NPF event (Shen et al., 2011). Due to the lack of direct measurements of particle light scattering coefficients $\left(\sigma_{\mathrm{sp}}\right)$, its values were reconstructed based on the measured number size distributions of dry particles employing a Mie model (Bohren and Huffman, 1998). The size-segregated particle scattering distributions were simulated according to Cheng et al. (2008). The refractive index used in the Mie code was $1.55-0.05 i$, which was derived from the ambient measurement at another regional site (Yufa), south Beijing (Cheng et al., 2009). Note that the simulated particle light scattering coefficient represents the submicrometer aerosol, because the coarse particles $(>1 \mu \mathrm{m})$ were not included in the calculations. They could contribute around $10 \%$ to the total particle scattering coefficient (Cheng et al., 2008). Considering that the particle scattering could be also affected by other parameters such as particle chemical compositions and mixing state (Cheng et al., 2006), most of which are quite different in diverse environments, the quantity of the differences will hence not be evaluated further in this study.

In terms of the influence of NPF on the number concentration of potential CCN, most field observations (Kuang et al., 2009; Kuwata et al., 2008; Wiedensohler et al., 2009) 
Table 2. Statistics of condensable vapor concentration $(C)$, condensation sink $(C S)$ and source rate $(Q)$ during the NPF event over the three seasons and whole measurement period. CS is the median value during the time frame for determination of GR.

\begin{tabular}{ll|rr|rr|rr}
\hline & \# Event & CS $\left(\times 10^{-2} \mathrm{~s}^{-1}\right)$ & \multicolumn{2}{|c|}{$C\left(\times 10^{7} \mathrm{~cm}^{-3}\right)$} & $Q\left(\times 10^{6} \mathrm{~cm}^{-3} \mathrm{~s}^{-1}\right)$ \\
\cline { 2 - 8 } & PKU/SDZ & PKU & SDZ & PKU & SDZ & PKU & SDZ \\
\hline Spring & $29 / 26$ & $2.6 \pm 1.4$ & $2.4 \pm 2.1$ & $8.7 \pm 2.9$ & $7.7 \pm 2.8$ & $2.2 \pm 0.4$ & $1.8 \pm 0.6$ \\
Summer & $18 / 10$ & $2.2 \pm 1.0$ & $0.9 \pm 0.8$ & $11.6 \pm 5.7$ & $7.9 \pm 3.8$ & $2.5 \pm 0.6$ & $0.7 \pm 0.3$ \\
Autumn & $20 / 33$ & $1.7 \pm 1.2$ & $0.9 \pm 0.6$ & $8.1 \pm 2.2$ & $6.4 \pm 3.1$ & $1.4 \pm 0.3$ & $0.6 \pm 0.2$ \\
Average in total & $67 / 69$ & $2.2 \pm 1.3$ & $1.4 \pm 1.6$ & $9.3 \pm 4.0$ & $7.1 \pm 3.2$ & $2.1 \pm 0.5$ & $1.2 \pm 0.5$ \\
\hline
\end{tabular}

demonstrated that a large fraction of newly formed particles could grow in the size range of $\mathrm{CCN}$ within the same day. However, quantitative determination of $\mathrm{CCN}$ number concentration is not possible without direct measurements or detailed information on the volume fractions of chemical compositions. Since such data are not available during the investigated period, we have to rely on some surrogate measures for the CCN number concentration. The idea to estimate the production of potential $\mathrm{CCN}$ is based on the assumption that particles larger than a certain particle size could serve as CCN (Kerminen et al., 2012; Laaksonen et al., 2005; Lihavainen et al., 2003). Three quantities $-\mathrm{CCN}_{45}, \mathrm{CCN}_{90}$ and $\mathrm{CCN}_{200}$, namely the number concentrations of particles larger than $45 \mathrm{~nm}, 90 \mathrm{~nm}$ and $200 \mathrm{~nm}$ in dry diameter, respectively - are selected to represent the "potential" CCN number concentrations. This selection can be considered justified, because the field observations during the HaChi (Haze in China) summer campaign in the North China Plain (Wuqing site) showed activation diameters of $200 \mathrm{~nm}, 170 \mathrm{~nm}, 90 \mathrm{~nm}$, $70 \mathrm{~nm}$ and $45 \mathrm{~nm}$ at super saturations of $0.058 \%, 0.085 \%$, $0.18 \%, 0.36 \%$ and $0.72 \%$, respectively (Deng et al., 2011).

It also should be clarified that we potentially produce misunderstandings on estimating the contributions of NPF to $\mathrm{CCN}$ number concentration. Potential CCN in the ambient atmosphere could be formed in the following three ways: (1) primary particles able to act as $\mathrm{CCN}$ directly, (2) CCN resulting from NPF and subsequent growth, and (3) primary particles that cannot originally act as $\mathrm{CCN}$ but become $\mathrm{CCN}$ after aging (growth and addition of hygroscopic material). It is thus extremely difficult to distinguish the contributions of diverse sources to the enhancement of the $\mathrm{CCN}$ number concentration. Particularly, we assumed that all due to NPF, in fact, might also be contributed by the third way (primary emission or the following aging process), especially in a polluted urban environment with the intensive primary emissions by anthropogenic activity. Nevertheless, these effects could be less important at the regional site SDZ. Hence, in this section, we only pay attention to the regional NPF events observed concurrently at both sites (total 34 events in Class I type). The potential contributions of regional NPF events to the enhancement of the number concentration of potential CCN are firstly calculated for the regional and urban sites. The difference can be mainly estimated as the contri- bution of anthropogenic emissions in polluted urban environments. Note the regional transportation between these two sites was not evaluated in quantity in this study, which might also cause uncertainties.

Figure 4 reveals an example of simultaneous NPF events observed both at PKU and SDZ on 26 September 2008. New particles were nucleated around 09:00 in the morning followed by a significant growth to larger particles $(\sim 70 \mathrm{~nm})$ indicated by the "banana-shaped" temporal developments of the particle number size distributions (Fig. $4 \mathrm{a}$ and b). The number concentrations of the nucleation mode $\left(N_{3-25}\right)$ as well as all particles $\left(N_{3-900}\right)$ were shown in Fig. $4 \mathrm{c}$ and d. At the PKU site, the maximum of $N_{3-25}$ and $N_{3-900}$ were $52300 \mathrm{~cm}^{-3}$ and $60300 \mathrm{~cm}^{-3}$, respectively. On the contrary, the total particle number concentration was dominated by the nucleation mode (up to $93 \%$ ) at the beginning of the nucleation event at SDZ (also see a much smaller accumulation mode at SDZ compared to PKU in Fig. 5a and b). The mean condensation sink before nucleation events started (08:0011:00) was $0.007 \mathrm{~s}^{-1}$ at PKU, which was almost one order of magnitude higher than that at SDZ $\left(0.001 \mathrm{~s}^{-1}\right)$. However, the particle formation and growth rates were $9.8 \mathrm{~cm}^{-3} \mathrm{~s}^{-1}$ and $4.5 \mathrm{~nm} \mathrm{~h}^{-1}$ at PKU, as well as $4.3 \mathrm{~cm}^{-3} \mathrm{~s}^{-1}$ and $3.7 \mathrm{~nm} \mathrm{~h}^{-1}$ at SDZ, respectively, indicating that more condensable vapor contributed to the particle nucleation and growth processes in polluted urban Beijing.

The estimated particle light scattering coefficients $(550 \mathrm{~nm})$ and particle mass concentrations are presented in Fig. $4 \mathrm{e}$ and $\mathrm{f}$. The particle mass concentrations were calculated from particle number size distributions assuming spherical particles and a density of $1.6 \mathrm{~g} \mathrm{~cm}^{-3}$, which was derived from a previous study in Beijing (Hu et al., 2012). Obviously, strong correlations $\left(R^{2}=0.99\right)$ were observed between particle scattering coefficients and particle mass concentrations at both sites. At the PKU site, the particle light scattering coefficients and mass concentrations showed a significant increase from 15:00 to 23:00, with average growth rates of 13.9 $\mathrm{Mm}^{-1} \mathrm{~h}^{-1}$ and $4.5 \mu \mathrm{g} \mathrm{m}^{-3} \mathrm{~h}^{-1}$, respectively. At SDZ, these two parameters exhibited as well a continuous increase until midnight. The growth rates were $7.8 \mathrm{Mm}^{-1} \mathrm{~h}^{-1}$ and $1.7 \mu \mathrm{g} \mathrm{m}^{-3} \mathrm{~h}^{-1}$, respectively.

In order to demonstrate the influence of the nucleation events, we also calculated the size-segregated light scattering 


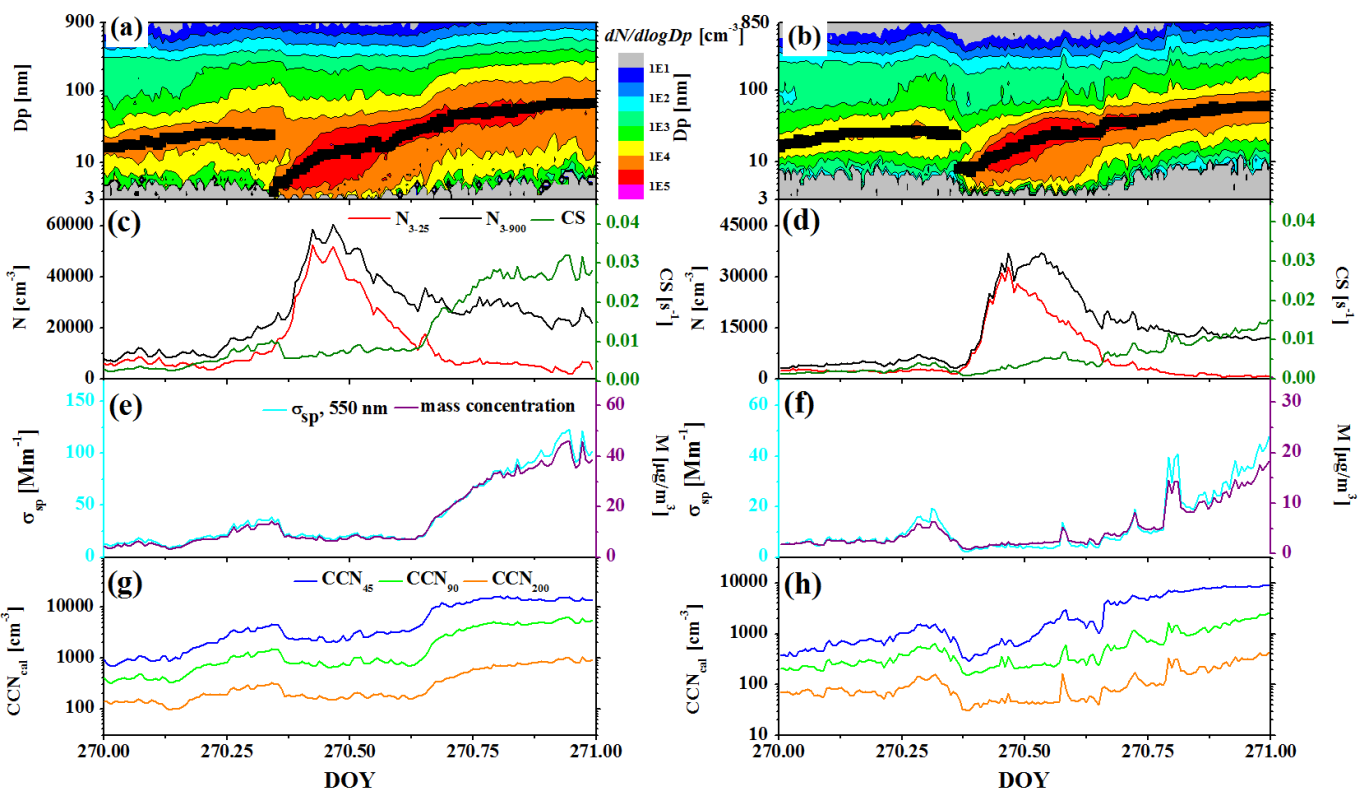

Fig. 4. (a, b) The particle number size distributions and mean diameters of the dominating mode (black square); (c, d) the evolution of condensation sink (CS, olive) and the number concentrations of nucleation mode $\left(N_{3-25}\right.$, red) and total $\left(N_{3-900}\right.$, black) particles; (e, f) the simulated particle light scattering coefficient at $550 \mathrm{~nm}\left(\sigma_{\mathrm{sp}}\right.$, cyan) and mass concentration $(\mathrm{M}$, purple); and $(\mathrm{g}$, h) the calculated CCN number concentration $\left(\mathrm{CCN}_{\mathrm{cal}}\right)$ in certain diameter ranges $(45-900 \mathrm{~nm}$, blue; $90-900 \mathrm{~nm}$, green; $200-900 \mathrm{~nm}$, orange).

PKU
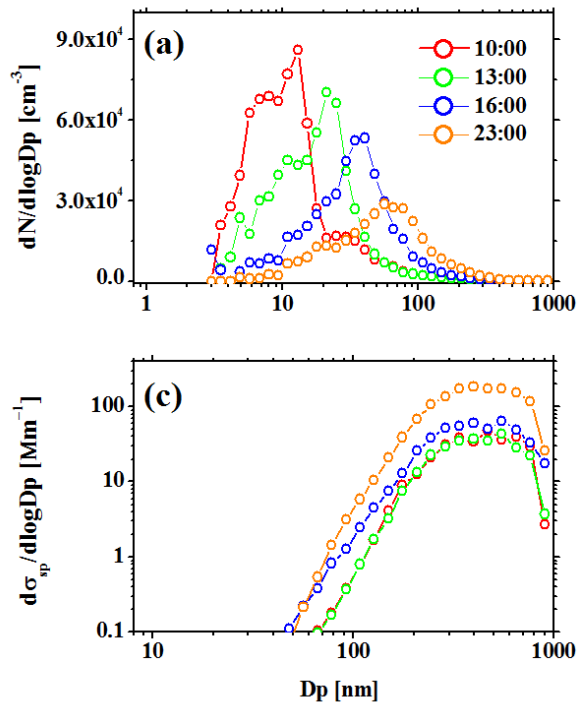

SDZ
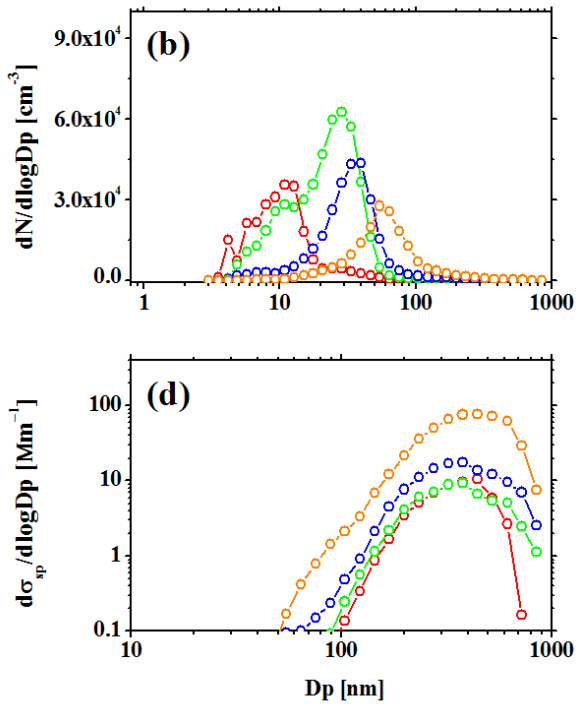

Fig. 5. Evolutions of (a, b) the particle number size distributions measured by TDMPS and (c, $\mathbf{d})$ the simulated particle light scattering size distributions at $550 \mathrm{~nm}$ from about 10:00 (local time) to midnight (23:00) on 26 September 2008. Left and right panels represent the PKU and SDZ sites, respectively.

distributions at both sites (Fig. 5c and d). In theory, the light scattering of a $100 \mathrm{~nm}$ particle at wavelength of $550 \mathrm{~nm}$ is approximately two orders and three orders of magnitude smaller than those of 200 and $500 \mathrm{~nm}$, respectively. This means in general the light scattering is dominated by rel- atively large accumulation mode particles (>100 nm). As shown in Figs. 5a and 6b, one can clearly see the continuous growth in particle size at both sites from original nucleation mode $(\sim 10 \mathrm{~nm})$ in the late morning (10:00, local time) through the Aitken and accumulation modes before the 
Table 3. Statistics of three quantities $\left(\mathrm{CCN}_{45}, \mathrm{CCN}_{90}\right.$ and $\left.\mathrm{CCN}_{200}\right)$ at two sites and the potential contributions of anthropogenic emissions.

\begin{tabular}{lrr|rr|rrr}
\hline & \multicolumn{2}{c|}{ PKU_average } & \multicolumn{2}{c|}{ SDZ_average } & \multicolumn{2}{c}{ Anthropogenic emissions (\%) } \\
\cline { 2 - 7 } & $\begin{array}{r}\text { Increase number } \\
\left(\times 10^{3} \mathrm{~cm}^{-3}\right)\end{array}$ & Increase factor & $\begin{array}{r}\text { Increase number } \\
\left(\times 10^{3} \mathrm{~cm}^{-3}\right)\end{array}$ & Increase factor & Min & Max & Average \\
\hline $\mathrm{CCN}_{45}$ & $13.0 \pm 4.7$ & $5.6 \pm 3.5$ & $7.7 \pm 6.1$ & $8.7 \pm 7.6$ & 13 & 91 & $59 \pm 23$ \\
$\mathrm{CCN}_{90}$ & $5.7 \pm 2.6$ & $6.0 \pm 3.9$ & $3.4 \pm 3.1$ & $7.0 \pm 6.5$ & 20 & 95 & $63 \pm 24$ \\
$\mathrm{CCN}_{200}$ & $1.2 \pm 0.7$ & $5.6 \pm 3.7$ & $0.8 \pm 0.7$ & $6.5 \pm 6.3$ & 10 & 94 & $62 \pm 25$ \\
\hline
\end{tabular}

clear drop-down of boundary layer height (e.g., 16:00 LT). Because of that, the scattering coefficient due to the particle nucleation and subsequent condensable growth kept increasing (Fig. $5 \mathrm{c}$ and d). Nevertheless, the contribution by ultrafine particles $\left(D_{\mathrm{p}}<100 \mathrm{~nm}\right)$ to total particle light scattering was still negligible $(<1 \%)$. In addition, the condensational growth for particles larger than $100 \mathrm{~nm}$ became very slow in terms of diameter changes (Cheng et al., 2012). However, the large number of grown particles might, through the subsequent coagulation process, grow in a larger size range (Seinfeld and Pandis, 2006), where they could contribute more efficiently to the particle light scattering as well as particle mass concentration. For example, at 16:00 LT, a significant increase in scattering size distribution within nearly the full size range from about 40 to $900 \mathrm{~nm}$ can be observed at both sites, especially at SDZ.

The variations of $\mathrm{CCN}$ number concentrations are displayed in Fig. $4 \mathrm{~g}$ and h. $\mathrm{CCN}_{45}$ showed a simultaneous increase with the nucleation mode particles at both sites. However, the enhancements in $\mathrm{CCN}_{90}$ and $\mathrm{CCN}_{200}$ were several hours later. To quantify the enhancements of three parameters $\left(\mathrm{CCN}_{45}, \mathrm{CCN}_{90}\right.$ and $\left.\mathrm{CCN}_{200}\right)$, we first determined time $t_{1}$ and $t_{2}$ when these parameters reached the minimum and maximum, respectively, during the time frame for the determination of particle growth rate. The increase was then denoted from the differences between their minimum and maximum, which were calculated by averaging over $t_{1} \pm 0.5 \mathrm{~h}$ and $t_{2} \pm 0.5 \mathrm{~h}$ to decrease the uncertainties. Although these estimated values might not represent the real conditions, we could still see the influences of new particle formation and subsequent condensational growth on potential $\mathrm{CCN}$ productions.

The lowest $\mathrm{CCN}_{45}, \mathrm{CCN}_{90}$ and $\mathrm{CCN}_{200}$ were $2200 \mathrm{~cm}^{-3}$, $700 \mathrm{~cm}^{-3}$ and $160 \mathrm{~cm}^{-3}$ during the event, respectively, and gradually rose to the maximum values of $15600 \mathrm{~cm}^{-3}$, $5600 \mathrm{~cm}^{-3}$ and $900 \mathrm{~cm}^{-3}$ for PKU. By the end of the day, the enhancement factors at high and median supersaturations $(0.72 \%$ and $0.18 \%)$ were higher than at low supersaturation $(0.058 \%)$, with the values of 7.0, 7.8 and 5.5, respectively. The high simulated CCN number concentrations were comparable with the observations at Yufa, during the CAREBeijing 2006 campaign (Gunthe et al., 2011; Wiedensohler et al., 2009), suggesting the particle nucleation is important for the formation of $\mathrm{CCN}$ in the megacity Beijing. Contrary to ur- ban environments, these three quantities increased by factors of 24.3, 13.6 and 10.5 at SDZ. The higher CCN enhancement factors at SDZ might be due to the lower pre-existing particles at the initial time. However, in absolute terms, the increasing $\mathrm{CCN}_{45}, \mathrm{CCN}_{90}$ and $\mathrm{CCN}_{200}$ were $4900 \mathrm{~cm}^{-3}$, $2600 \mathrm{~cm}^{-3}$ and $370 \mathrm{~cm}^{-3}$ higher at the urban site compared to the regional site, respectively, implying that the potential contributions of anthropogenic emissions to $\mathrm{CCN}$ number concentrations were $37 \%, 54 \%$ and $50 \%$ in this case.

On average, the regional nucleation and the following secondary aerosol formation resulted in the enhancements of $\mathrm{CCN}$ number concentrations $\left(\mathrm{CCN}_{45}, \mathrm{CCN}_{90}\right.$ and $\left.\mathrm{CCN}_{200}\right)$ with factors of 5.6, 6.0 and 5.6 at PKU, respectively, and 8.7, 7.0 and 6.5 at SDZ (see Table 3). This result indicated very clearly that atmospheric new particle formation is an extremely important source of new "potential" CCN over the North China Plain. Moreover, the potential contribution by the anthropogenic emissions to $\mathrm{CCN}$ number concentration should be concerned at the urban site, with average fraction in the range of $59-63 \%$.

\section{Conclusions}

To investigate the characteristics of regional new particle formation events in the North China Plain, simultaneous measurements of particle number size distributions had been carried out at urban site PKU and regional site SDZ from March to November in 2008. Both stations have been equipped with a dual mobility particle size spectrometer, type TROPOSTDMPS.

In total, the frequencies of nucleation event were $38 \%$ and $39 \%$ at urban and regional background sites, respectively, with 52 regional NPF events at both places during the whole measurement period. The seasonal variations of NPF event occurrence were similar at both sites with more events in spring and the lowest number during the summertime.

Apparent particle formation rates were in the range of $2.2-34.5 \mathrm{~cm}^{-3} \mathrm{~s}^{-1}$ at PKU, which were higher than those at SDZ site $\left(0.4-24.5 \mathrm{~cm}^{-3} \mathrm{~s}^{-1}\right)$. The mean growth rates were $5.2 \mathrm{~nm} \mathrm{~h}^{-1}$ and $4.0 \mathrm{~nm} \mathrm{~h}^{-1}$ at PKU and SDZ, respectively. Before the nucleation event started (08:00-11:00), more preexisting particles were observed in a polluted urban environment than that at the regional site. The mean values of 
condensation sink were $0.025 \mathrm{~s}^{-1}$ at PKU and $0.016 \mathrm{~s}^{-1}$ at SDZ, respectively, which were both significantly higher than the measurements in European cities. Overall, the background conditions of the NPF event in the North China Plain could be characterized as the higher precursor vapor concentration and pre-existing particles, even in the regional background environment.

The secondary aerosol formation following NPF results in an increase in the particle mass concentration and scattering coefficient, as well as $\mathrm{CCN}$ production. Three quantities - $\mathrm{CCN}_{45}, \mathrm{CCN}_{90}$ and $\mathrm{CCN}_{200}$ - were selected to estimate the "potential" $\mathrm{CCN}$ number concentrations. On the average of 34 selected cases with significant growth pattern, $\mathrm{CCN}_{45}$, $\mathrm{CCN}_{90}$ and $\mathrm{CCN}_{200}$ number concentrations were enhanced by factors of 5.6, 6.0 and 5.6 at PKU, respectively, and 8.7, 7.0 and 6.5 at SDZ. In addition, more than half (59-63\%) of the contribution to the $\mathrm{CCN}$ productions could be owed to the anthropogenic emissions in the polluted urban environment, which should be paid more attention to in regional and global climate models. Meanwhile, the simultaneous measurements of particle and CCN number size distributions, as well as the chemical components of fine particles, are needed in the further studies.

Acknowledgements. This work was supported by the National Natural Science Foundation of China (21025728, 21190052 and 41175113), the National Basic Research Program (973) of China (2011CB403401 and 2013CB228503), the China Ministry of Environmental Protection's Special Funds for Scientific Research on Public Welfare (201009002) and European Integrated project on Aerosol, Cloud, Climate, and Air Quality Interactions, EUCAARI (036833).

Edited by: V.-M. Kerminen

\section{References}

Bae, M.-S., Schwab, J. J., Hogrefe, O., Frank, B. P., Lala, G. G., and Demerjian, K. L.: Characteristics of size distributions at urban and rural locations in New York, Atmos. Chem. Phys., 10, 45214535, doi:10.5194/acp-10-4521-2010, 2010.

Berndt, T., Böge, O., Stratmann, F., Heintzenberg, J., and Kulmala, M.: Rapid formation of sulfuric acid particles at near-atmospheric conditions, Science, 307, 698-700, doi:10.1126/science.1104054, 2005.

Birmili, W., Stratmann, F., and Wiedensohler, A.: Design of a DMA-based size spectrometer for a large particle size range and stable operation, J. Aerosol Sci., 30, 549-553, doi:10.1016/S0021-8502(98)00047-0, 1999.

Birmili, W., Berresheim, H., Plass-Dülmer, C., Elste, T., Gilge, S., Wiedensohler, A., and Uhrner, U.: The Hohenpeissenberg aerosol formation experiment (HAFEX): a long-term study including size-resolved aerosol, $\mathrm{H}_{2} \mathrm{SO}_{4}, \mathrm{OH}$, and monoterpenes measurements, Atmos. Chem. Phys., 3, 361-376, doi:10.5194/acp-3-361-2003, 2003.
Bohren, C. F. and Huffman, D. R.: Absorption and scattering of light by small particles, John Wiley and Sons, Wiley-Intersci, New York, 544, 1998.

Chen, M., Titcombe, M., Jiang, J., Jen, C., Kuang, C., Fischer, M. L., Eisele, F. L., Siepmann, J. I., Hanson, D. R., Zhao, J., and McMurry, P. H.: Acid-base chemical reaction model for nucleation rates in the polluted atmospheric boundary layer, P. Natl. Acad. Sci. USA, 109, 18713-18718, doi:10.1073/pnas.1210285109, 2012.

Cheng, Y. F., Eichler, H., Wiedensohler, A., Heintzenberg, J., Zhang, Y. H., Hu, M., Herrmann, H., Zeng, L. M., Liu, S., Gnauk, T., Brüggemann, E., and He, L. Y.: Mixing state of elemental carbon and non-light-absorbing aerosol components derived from in situ particle optical properties at Xinken in Pearl River Delta of China, J. Geophys. Res.-Atmos., 111, D20204, doi:10.1029/2005JD006929, 2006.

Cheng, Y. F., Wiedensohler, A., Eichler, H., Su, H., Gnauk, T., Brüggemann, E., Herrmann, H., Heintzenberg, J., Slanina, J., Tuch, T., Hu, M., and Zhang, Y. H.: Aerosol optical properties and related chemical apportionment at Xinken in Pearl River Delta of China, Atmos. Environ., 42, 6351-6372, doi:10.1016/j.atmosenv.2008.02.034, 2008.

Cheng, Y. F., Berghof, M., Garland, R. M., Wiedensohler, A., Wehner, B., Muller, T., Su, H., Zhang, Y. H., Achtert, P., Nowak, A., Poschl, U., Zhu, T., Hu, M., and Zeng, L. M.: Influence of soot mixing state on aerosol light absorption and single scattering albedo during air mass aging at a polluted regional site in northeastern China, J. Geophys. Res., 114, D00G10, doi:10.1029/2008jd010883, 2009.

Cheng, Y. F., Su, H., Rose, D., Gunthe, S. S., Berghof, M., Wehner, B., Achtert, P., Nowak, A., Takegawa, N., Kondo, Y., Shiraiwa, M., Gong, Y. G., Shao, M., Hu, M., Zhu, T., Zhang, Y. H., Carmichael, G. R., Wiedensohler, A., Andreae, M. O., and Pöschl, U.: Size-resolved measurement of the mixing state of soot in the megacity Beijing, China: diurnal cycle, aging and parameterization, Atmos. Chem. Phys., 12, 4477-4491, doi:10.5194/acp-12-4477-2012, 2012.

Dal Maso, M., Kulmala, M., Riipinen, I., Wagner, R., Hussein, T., Aalto, P. P., and Lehtinen, K. E. J.: Formation and growth of fresh atmospheric aerosols: eight years of aerosol size distribution data from SMEAR II, Hyytiala, Finland, Boreal Env. Res., 10, 323 336, 2005.

Dal Maso, M., Sogacheva, L., Aalto, P. P., Riipinen, I., Komppula, M., Tunved, P., Korhonen, L., Suur-Uski, V., Hirsikko, A., KurtÉN, T., Kerminen, V.-M., Lihavainen, H., Viisanen, Y., Hansson, H.-C., and Kulmala, M.: Aerosol size distribution measurements at four Nordic field stations: identification, analysis and trajectory analysis of new particle formation bursts, Tellus B, 59, 350-361, doi:10.1111/j.1600-0889.2007.00267.x, 2007.

Deng, Z. Z., Zhao, C. S., Ma, N., Liu, P. F., Ran, L., Xu, W. Y., Chen, J., Liang, Z., Liang, S., Huang, M. Y., Ma, X. C., Zhang, Q., Quan, J. N., Yan, P., Henning, S., Mildenberger, K., Sommerhage, E., Schäfer, M., Stratmann, F., and Wiedensohler, A.: Size-resolved and bulk activation properties of aerosols in the North China Plain, Atmos. Chem. Phys., 11, 3835-3846, doi:10.5194/acp-11-3835-2011, 2011.

Du, J., Cheng, T., Zhang, M., Chen, J., He, Q., Wang, X., Zhang, R., Tao, J., Huang, G., Li, X., and Zha, S.: Aerosol Size Spectra and Particle Formation Events at Urban Shang- 
hai in Eastern China, Aerosol Air Qual. Res., 12, 1362-1372, doi:10.4209/aaqr.2011.12.0230, 2012.

Dunn, M. J., Jimenez, J. L., Baumgardner, D., Castro, T., McMurry, P. H., and Smith, J. N.: Measurements of Mexico City nanoparticle size distributions: Observations of new particle formation and growth, Geophys. Res. Lett., 31, L10102, doi:10.1029/2004g1019483, 2004.

Fuchs, N. A.: The mechanics of aerosols, Dover, New York, 1964.

Gao, J., Wang, T., Zhou, X., Wu, W., and Wang, W.: Measurement of aerosol number size distributions in the Yangtze River delta in China: Formation and growth of particles under polluted conditions, Atmos. Environ., 43, 829-836, doi:10.1016/j.atmosenv.2008.10.046, 2009.

Gao, J., Chai, F., Wang, T., and Wang, W.: Particle number size distribution and new particle formation (NPF) in Lanzhou, Western China, Particuology, 9, 611-618, doi:10.1016/j.partic.2011.06.008, 2011.

Gunthe, S. S., Rose, D., Su, H., Garland, R. M., Achtert, P., Nowak, A., Wiedensohler, A., Kuwata, M., Takegawa, N., Kondo, Y., Hu, M., Shao, M., Zhu, T., Andreae, M. O., and Pöschl, U.: Cloud condensation nuclei (CCN) from fresh and aged air pollution in the megacity region of Beijing, Atmos. Chem. Phys., 11, 1102311039, doi:10.5194/acp-11-11023-2011, 2011.

Guo, H., Wang, D. W., Cheung, K., Ling, Z. H., Chan, C. K., and Yao, X. H.: Observation of aerosol size distribution and new particle formation at a mountain site in subtropical Hong Kong, Atmos. Chem. Phys., 12, 9923-9939, doi:10.5194/acp-12-99232012, 2012.

Herrmann, E., Ding, A. J., Petäjä, T., Yang, X. Q., Sun, J. N., Qi, X. M., Manninen, H., Hakala, J., Nieminen, T., Aalto, P. P., Kerminen, V.-M., Kulmala, M., and Fu, C. B.: New particle formation in the western Yangtze River Delta: first data from SORPES-station, Atmos. Chem. Phys. Discuss., 13, 1455-1488, doi:10.5194/acpd-13-1455-2013, 2013.

Hu, M., Peng, J., Sun, K., Yue, D., Guo, S., Wiedensohler, A., and $\mathrm{Wu}, \mathrm{Z}$.: Estimation of Size-Resolved Ambient Particle Density Based on the Measurement of Aerosol Number, Mass, and Chemical Size Distributions in the Winter in Beijing, Environ. Sci. Technol., 46, 9941-9947, doi:10.1021/es204073t, 2012.

Hussein, T., Martikainen, J., Junninen, H., Sogacheva, L., Wagner, R., Dal Maso, M., Riipinen, I., Aalto, P. P., and Kulmala, M.: Observation of regional new particle formation in the urban atmosphere, Tellus B, 60, 509-521, doi:10.1111/j.16000889.2008.00365.x, 2008.

Hussein, T., Junninen, H., Tunved, P., Kristensson, A., Dal Maso, M., Riipinen, I., Aalto, P. P., Hansson, H.-C., Swietlicki, E., and Kulmala, M.: Time span and spatial scale of regional new particle formation events over Finland and Southern Sweden, Atmos. Chem. Phys., 9, 4699-4716, doi:10.5194/acp-9-4699-2009, 2009.

IPCC: Intergovernmental Panel on Climate Change, Report, Cambridge University Press: Cambridge, UK, 2007.

Jung, J., Miyazaki, Y., and Kawamura, K.: Different characteristics of new particle formation between urban and deciduous forest sites in Northern Japan during the summers of 2010-2011, Atmos. Chem. Phys., 13, 51-68, doi:10.5194/acp-13-51-2013, 2013.

Kerminen, V.-M., Paramonov, M., Anttila, T., Riipinen, I., Fountoukis, C., Korhonen, H., Asmi, E., Laakso, L., Lihavainen, H.,
Swietlicki, E., Svenningsson, B., Asmi, A., Pandis, S. N., Kulmala, M., and Petäjä, T.: Cloud condensation nuclei production associated with atmospheric nucleation: a synthesis based on existing literature and new results, Atmos. Chem. Phys., 12, 12037 12059, doi:10.5194/acp-12-12037-2012, 2012.

Kivekäs, N., Sun, J., Zhan, M., Kerminen, V.-M., Hyvärinen, A., Komppula, M., Viisanen, Y., Hong, N., Zhang, Y., Kulmala, M., Zhang, X.-C., Deli-Geer, and Lihavainen, H.: Long term particle size distribution measurements at Mount Waliguan, a highaltitude site in inland China, Atmos. Chem. Phys., 9, 5461-5474, doi:10.5194/acp-9-5461-2009, 2009.

Kuang, C., McMurry, P. H., and McCormick, A. V.: Determination of cloud condensation nuclei production from measured new particle formation events, Geophys. Res. Lett., 36, L09822, doi:10.1029/2009g1037584, 2009.

Kulmala, M., Maso, M. D., Mäkelä, J. M., Pirjola, L., Väkevä, M., Aalto, P., Miikkulainen, P., Hämeri, K., and O’Dowd, C. D.: On the formation, growth and composition of nucleation mode particles, Tellus B, 53, 479-490, 2001.

Kulmala, M., Vehkamäki, H., Petäjä, T., Dal Maso, M., Lauri, A., Kerminen, V.-M., Birmili, W., and McMurry, P. H.: Formation and growth rates of ultrafine atmospheric particles: a review of observations, J. Aerosol Sci., 35, 143-176, doi:10.1016/j.jaerosci.2003.10.003, 2004.

Kulmala, M., Petäjä, T., Mönkkönen, P., Koponen, I. K., Dal Maso, M., Aalto, P. P., Lehtinen, K. E. J., and Kerminen, V.-M.: On the growth of nucleation mode particles: source rates of condensable vapor in polluted and clean environments, Atmos. Chem. Phys., 5, 409-416, doi:10.5194/acp-5-409-2005, 2005.

Kulmala, M., Petäjä, T., Nieminen, T., Sipilä, M., Manninen, H. E., Lehtipalo, K., Dal Maso, M., Aalto, P. P., Junninen, H., Paasonen, P., Riipinen, I., Lehtinen, K. E. J., Laaksonen, A., and Kerminen, V.-M.: Measurement of the nucleation of atmospheric aerosol particles, Nat. Protocols, 7, 1651-1667, doi:10.1038/nprot.2012.091, 2012.

Kuwata, M., Kondo, Y., Miyazaki, Y., Komazaki, Y., Kim, J. H., Yum, S. S., Tanimoto, H., and Matsueda, H.: Cloud condensation nuclei activity at Jeju Island, Korea in spring 2005, Atmos. Chem. Phys., 8, 2933-2948, doi:10.5194/acp-8-2933-2008, 2008.

Laaksonen, A., Hamed, A., Joutsensaari, J., Hiltunen, L., Cavalli, F., Junkermann, W., Asmi, A., Fuzzi, S., and Facchini, M. C.: Cloud condensation nucleus production from nucleation events at a highly polluted region, Geophys. Res. Lett., 32, L06812, doi:10.1029/2004g1022092, 2005.

Lee, S. H., Reeves, J. M., Wilson, J. C., Hunton, D. E., Viggiano, A. A., Miller, T. M., Ballenthin, J. O., and Lait, L. R.: Particle Formation by Ion Nucleation in the Upper Troposphere and Lower Stratosphere, Science, 301, 1886-1889, doi:10.1126/science.1087236, 2003.

Li, W. J., Zhang, D. Z., Shao, L. Y., Zhou, S. Z., and Wang, W. $\mathrm{X}$.: Individual particle analysis of aerosols collected under haze and non-haze conditions at a high-elevation mountain site in the North China plain, Atmos. Chem. Phys., 11, 11733-11744, doi:10.5194/acp-11-11733-2011, 2011.

Lihavainen, H., Kerminen, V. M., Komppula, M., Hatakka, J., Aaltonen, V., Kulmala, M., and Viisanen, Y.: Production of "potential" cloud condensation nuclei associated with atmospheric new- 
particle formation in northern Finland, J. Geophys. Res., 108, 4782, doi:10.1029/2003jd003887, 2003.

Lin, P., Hu, M., Wu, Z., Niu, Y., and Zhu, T.: Marine aerosol size distributions in the springtime over China adjacent seas, Atmos. Environ., 41, 6784-6796, doi:10.1016/j.atmosenv.2007.04.045, 2007.

Liu, S., Hu, M., Wu, Z. J., Wehner, B., Wiedensohler, A., and Cheng, Y. F.: Aerosol number size distribution and new particle formation at a rural/coastal site in Pearl River Delta (PRD) of China, Atmos. Environ., 42, 6275-6283, doi:10.1016/j.atmosenv.2008.01.063, 2008.

Lohmann, U. and Feichter, J.: Global indirect aerosol effects: a review, Atmos. Chem. Phys., 5, 715-737, doi:10.5194/acp-5-7152005, 2005.

McMurry, P. H., Fink, M., Sakurai, H., Stolzenburg, M. R., Mauldin, R. L., Smith, J., Eisele, F., Moore, K., Sjostedt, S., Tanner, D., Huey, L. G., Nowak, J. B., Edgerton, E., and Voisin, D.: A criterion for new particle formation in the sulfur-rich Atlanta atmosphere, J. Geophys. Res., 110, D22S02, doi:10.1029/2005jd005901, 2005.

Merikanto, J., Spracklen, D. V., Mann, G. W., Pickering, S. J., and Carslaw, K. S.: Impact of nucleation on global CCN, Atmos. Chem. Phys., 9, 8601-8616, doi:10.5194/acp-9-8601-2009, 2009.

Mönkkönen, P., Koponen, I. K., Lehtinen, K. E. J., Hämeri, K., Uma, R., and Kulmala, M.: Measurements in a highly polluted Asian mega city: observations of aerosol number size distribution, modal parameters and nucleation events, Atmos. Chem. Phys., 5, 57-66, doi:10.5194/acp-5-57-2005, 2005.

Nieminen, T., Lehtinen, K. E. J., and Kulmala, M.: Sub-10 nm particle growth by vapor condensation - effects of vapor molecule size and particle thermal speed, Atmos. Chem. Phys., 10, 97739779, doi:10.5194/acp-10-9773-2010, 2010.

O’Dowd, C. D., Hämeri, K., Mäkelä, J. M., Pirjola, L., Kulmala, M., Jennings, S. G., Berresheim, H., Hansson, H.-C., de Leeuw, G., Kunz, G. J., Allen, A. G., Hewitt, C. N., Jackson, A., Viisanen, Y., and Hoffmann, T.: A dedicated study of New Particle Formation and Fate in the Coastal Environment (PARFORCE): Overview of objectives and achievements, J. Geophys. Res., 107, 8108, doi:10.1029/2001jd000555, 2002.

Park, J., Sakurai, H., Vollmers, K., and McMurry, P. H.: Aerosol size distributions measured at the South Pole during ISCAT, Atmos. Environ., 38, 5493-5500, doi:10.1016/j.atmosenv.2002.12.001, 2004.

Petäjä, T., Kerminen, V.-M., Dal Maso, M., Junninen, H., Koponen, I. K., Hussein, T., Aalto, P. P., Andronopoulos, S., Robin, D., Hämeri, K., Bartzis, J. G., and Kulmala, M.: Submicron atmospheric aerosols in the surroundings of Marseille and Athens: physical characterization and new particle formation, Atmos. Chem. Phys., 7, 2705-2720, doi:10.5194/acp-72705-2007, 2007.

Qian, S., Sakurai, H., and McMurry, P. H.: Characteristics of regional nucleation events in urban East St. Louis, Atmos. Environ., 41, 4119-4127, doi:10.1016/j.atmosenv.2007.01.011, 2007.

Salma, I., Borsós, T., Weidinger, T., Aalto, P., Hussein, T., Dal Maso, M., and Kulmala, M.: Production, growth and properties of ultrafine atmospheric aerosol particles in an urban environment, Atmos. Chem. Phys., 11, 1339-1353, doi:10.5194/acp-111339-2011, 2011.
Seinfeld, J. H. and Pandis, S. N.: Atmospheric Chemistry and Physics, From Air Pollution to Climate Change, Wiley, New York, 2006.

Shen, X. J., Sun, J. Y., Zhang, Y. M., Wehner, B., Nowak, A., Tuch, T., Zhang, X. C., Wang, T. T., Zhou, H. G., Zhang, X. L., Dong, F., Birmili, W., and Wiedensohler, A.: First long-term study of particle number size distributions and new particle formation events of regional aerosol in the North China Plain, Atmos. Chem. Phys., 11, 1565-1580, doi:10.5194/acp-11-15652011, 2011.

Sipila, M., Berndt, T., Petaja, T., Brus, D., Vanhanen, J., Stratmann, F., Patokoski, J., Mauldin, R. L., Hyvarinen, A. P., Lihavainen, H., and Kulmala, M.: The Role of Sulfuric Acid in Atmospheric Nucleation, Science, 327, 1243-1246, doi:10.1126/science.1180315, 2010.

Stanier, C. O., Khlystov, A. Y., and Pandis, S. N.: Nucleation events during the Pittsburgh air quality study: Description and relation to key meteorological, gas phase, and aerosol parameters, Aerosol Sci. Technol., 38, 253-264, doi:10.1080/02786820390229570, 2004.

Tunved, P., Hansson, H.-C., Kulmala, M., Aalto, P., Viisanen, Y., Karlsson, H., Kristensson, A., Swietlicki, E., Dal Maso, M., Ström, J., and Komppula, M.: One year boundary layer aerosol size distribution data from five nordic background stations, Atmos. Chem. Phys., 3, 2183-2205, doi:10.5194/acp-3-2183-2003, 2003.

Venzac, H., Sellegri, K., Laj, P., Villani, P., Bonasoni, P., Marinoni, A., Cristofanelli, P., Calzolari, F., Fuzzi, S., Decesari, S., Facchini, M. C., Vuillermoz, E., and Verza, G. P.: High frequency new particle formation in the Himalayas, P. Natl. Acad. Sci USA, 105, 15666-15671, doi:10.1073/pnas.0801355105, 2008.

Wang, Z. B., Hu, M., Wu, Z. J., Yue, D. L., He, L. Y., Huang, X. F., Liu, X. G., and Wiedensohler, A.: Long-term measurements of particle number size distributions and the relationships with air mass history and source apportionment in the summer of Beijing, Atmos. Chem. Phys., 13, 10159-10170, doi:10.5194/acp13-10159-2013, 2013a.

Wang, Z. B., Hu, M., Wu, Z. J., Yue, D. L., Zheng, J., Zhang, R. Y., Pei, X. Y., Paasonen, P., Dal Maso, M., Boy, M., and Wiedensohler, A.: Investigation of the connections between atmospheric new particle formation and organics at an urban site of Beijing, Atmos. Chem. Phys. Discuss., 13, 3419-3450, doi:10.5194/acpd-13-3419-2013, 2013 b.

Wang, Z. B., Hu, M., Yue, D. L., He, L. Y., Huang, X. F., Yang, Q., Zheng, J., Zhang, R. Y., and Zhang, Y. H.: New particle formation in the presence of a strong biomass burning episode at a downwind rural site in PRD, China, Tellus B, 65, 19965 , doi:10.3402/tellusb.v65i0.19965, 2013c.

Weber, R. J., Marti, J. J., McMurry, P. H., Eisele, F. L., Tanner, D. J., and Jefferson, A.: Measurements of new particle formation and ultrafine particle growth rates at a clean continental site, J. Geophys. Res.-Atmos., 102, 4375-4385, doi:10.1029/96JD03656, 1997.

Wehner, B., Wiedensohler, A., Tuch, T. M., Wu, Z. J., Hu, M., Slanina, J., and Kiang, C. S.: Variability of the aerosol number size distribution in Beijing, China: New particle formation, dust storms, and high continental background, Geophys. Res. Lett., 31, L22108, doi:10.1029/2004g1021596, 2004. 
Wehner, B., Birmili, W., Ditas, F., Wu, Z., Hu, M., Liu, X., Mao, J., Sugimoto, N., and Wiedensohler, A.: Relationships between submicrometer particulate air pollution and air mass history in Beijing, China, 2004-2006, Atmos. Chem. Phys., 8, 6155-6168, doi:10.5194/acp-8-6155-2008, 2008.

Wiedensohler, A., Cheng, Y. F., Nowak, A., Wehner, B., Achtert, P., Berghof, M., Birmili, W., Wu, Z. J., Hu, M., Zhu, T., Takegawa, N., Kita, K., Kondo, Y., Lou, S. R., Hofzumahaus, A., Holland, F., Wahner, A., Gunthe, S. S., Rose, D., Su, H., and Pöschl, U.: Rapid aerosol particle growth and increase of cloud condensation nucleus activity by secondary aerosol formation and condensation: A case study for regional air pollution in northeastern China, J. Geophys. Res.-Atmos., 114, D00G08, doi:10.1029/2008jd010884, 2009.

Wiedensohler, A., Birmili, W., Nowak, A., Sonntag, A., Weinhold, K., Merkel, M., Wehner, B., Tuch, T., Pfeifer, S., Fiebig, M., Fjäraa, A. M., Asmi, E., Sellegri, K., Depuy, R., Venzac, H., Villani, P., Laj, P., Aalto, P., Ogren, J. A., Swietlicki, E., Williams, P., Roldin, P., Quincey, P., Hüglin, C., Fierz-Schmidhauser, R., Gysel, M., Weingartner, E., Riccobono, F., Santos, S., Grüning, C., Faloon, K., Beddows, D., Harrison, R., Monahan, C., Jennings, S. G., O’Dowd, C. D., Marinoni, A., Horn, H.-G., Keck, L., Jiang, J., Scheckman, J., McMurry, P. H., Deng, Z., Zhao, C. S., Moerman, M., Henzing, B., de Leeuw, G., Löschau, G., and Bastian, S.: Mobility particle size spectrometers: harmonization of technical standards and data structure to facilitate high quality long-term observations of atmospheric particle number size distributions, Atmos. Meas. Tech., 5, 657-685, doi:10.5194/amt5-657-2012, 2012.
Wu, Z. J., Hu, M., Liu, S., Wehner, B., Bauer, S., Ma ßling, A., Wiedensohler, A., Petäjä, T., Dal Maso, M., and Kulmala, M.: New particle formation in Beijing, China: Statistical analysis of a 1-year data set, J. Geophys. Res., 112, D09209, doi:10.1029/2006jd007406, 2007.

Wu, Z. J., Hu, M., Lin, P., Liu, S., Wehner, B., and Wiedensohler, A.: Particle number size distribution in the urban atmosphere of Beijing, China, Atmos. Environ., 42, 7967-7980, doi:10.1016/j.atmosenv.2008.06.022, 2008.

Yu, F., Wang, Z., Luo, G., and Turco, R.: Ion-mediated nucleation as an important global source of tropospheric aerosols, Atmos. Chem. Phys., 8, 2537-2554, doi:10.5194/acp-8-2537-2008, 2008.

Zhang, R., Khalizov, A., Wang, L., Hu, M., and Xu, W.: Nucleation and Growth of Nanoparticles in the Atmosphere, Chem. Rev., 112, 1957-2011, doi:10.1021/cr2001756, 2012. 